\title{
LYMPH SCROTUM: AN UNUSUAL UROLOGICAL PRESENTATION OF LYMPHATIC FILARIASIS. A CASE SERIES STUDY
}

Ana Maria AGUIAR-SANTOS(1), Marcela LEAL-CRUZ(1), Maria José NETTO(1), Arturo CARRERA(1), Guilherme LIMA(2) \& Abraham ROCHA(1)

\begin{abstract}
SUMMARY
Lymphatic filariasis (LF) causes a wide range of clinical signs and symptoms, including urogenital manifestations. Transmission control and disability/morbidity management/control are the two pillars of the overall elimination strategy for LF. Lymph scrotum is an unusual urological clinical presentation of LF with important medical, psychological, social and economic repercussions. A retrospective case series study was conducted on outpatients attended at the National Reference Service for Filariasis, in an endemic area for filariasis (Recife, Brazil), between 2000 and 2007. Over this period, 6,361 patients were attended and seven cases with lymph scrotum were identified. Mean patient age was 45 years (range, 26 to 64 years). Mean disease duration was 8.5 years (range, two to 15 years). All patients had evidence of filarial infection from at least one laboratory test (parasitological, antigen investigation or "filarial dance sign" on ultrasound). Six patients presented histories of urological surgery. The authors highlight the importance of the association between filarial infection and the inadequate surgical and clinical management of hydrocele in an endemic area, as risk factors for lymph scrotum. Thus, filarial infection should be routinely investigated in all individuals presenting urological morbidity within endemic areas, in order to identify likely links in the transmission chain.
\end{abstract}

KEYWORDS: Lymph scrotum; Lymphatic filariasis; Morbidity control; Scrotal lesion; Wuchereria bancrofti.

\section{INTRODUCTION}

Lymphatic filariasis (LF) is a vector-borne parasitic disease caused by three lymphatic-dwelling nematode parasites, namely Wuchereria bancrofti, Brugia malayi and B. timori ${ }^{9}$. LF is one of the leading causes of permanent and long-term disability in the world and has been targeted for elimination by an important task force $\mathrm{e}^{24,30,34}$.

The World Health Organization estimates that close to $20 \%$ of the world's population is living at risk of the disease, which affects 120 million people in at least 83 countries throughout the tropics and subtropics $^{33}$. More than 40 million people suffer from chronic forms of the disease (lymphedema, elephantiasis or hydrocele) caused by these nematodes ${ }^{31}$, and approximately 29 million men worldwide present urogenital manifestations of lymphatic filariasis ${ }^{3,26}$. Wuchereria bancrofti is the only lymphatic filarial parasite that induces genital diseases ${ }^{11}$.

Filariasis is an important cause of disability, both because of its social stigma and because of psychosocial damage and economic losses ${ }^{31}$. It is believed that around 15 to $20 \%$ of infected individuals may evolve to clinical filarial disease ${ }^{14}$. In Brazil, it is estimated that three million individuals live in areas considered to be at risk and approximately 49,000 people are infected with $W$. bancrofti. The largest sample is in the metropolitan area of Recife, in the northeastern region ${ }^{4,8,19,20,21}$.

Lymph scrotum or superficial scrotal lymphangiomatosis is a urogenital condition characterized by the presence of lymphatic vesicles on the surface of the scrotal skin that can easily rupture, giving rise to drainage of the whitish secretion typical of the disease (Fig. 1). This secretion serves as an excellent culturing medium that favors repeated bacterial infections. It may trigger progression of the condition to lymphedema and scrotal elephantiasis, the advanced stages of the disease $\mathrm{e}^{7,11,15}$.

The pathogenesis of the clinical forms caused by adult worms is known, with lymphangiectasia as the turning point in the natural history of the disease. However, the pathogenesis of lymph scrotum is not well defined ${ }^{15,17}$. There is scarce information in the literature about this morbid condition. Although lymph scrotum is a less frequent manifestation of LF, it has important medical, psychological and socioeconomic repercussions for individuals who present this condition. It seems to be the complication of LF that produces the greatest incapacitation among men ${ }^{11}$.

The aim of the present study was to provide support for diagnosis and therapeutic management of this chronic genital morbid condition and to draw attention to the clinical and surgical approaches towards hydrocele among patients living in an endemic area.

(1) Centro de Pesquisas Aggeu Magalhães, Serviço de Referência Nacional em Filarioses, Fundação Oswaldo Cruz, Recife, PE, Brasil.

(2) IMIP/Instituto Materno Infantil Prof. Fernando Figueira.

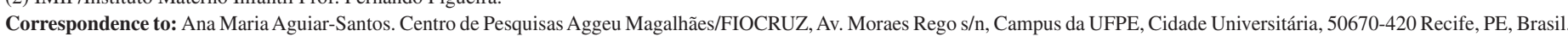
Tel: +55.81.2101-2573, Fax: +55.81.2101-2640. E-mail: amas@ cpqam.fiocruz.br 


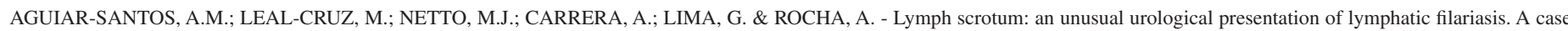
series study. Rev. Inst. Med. trop. S. Paulo, 51(4): 179-183, 2009.

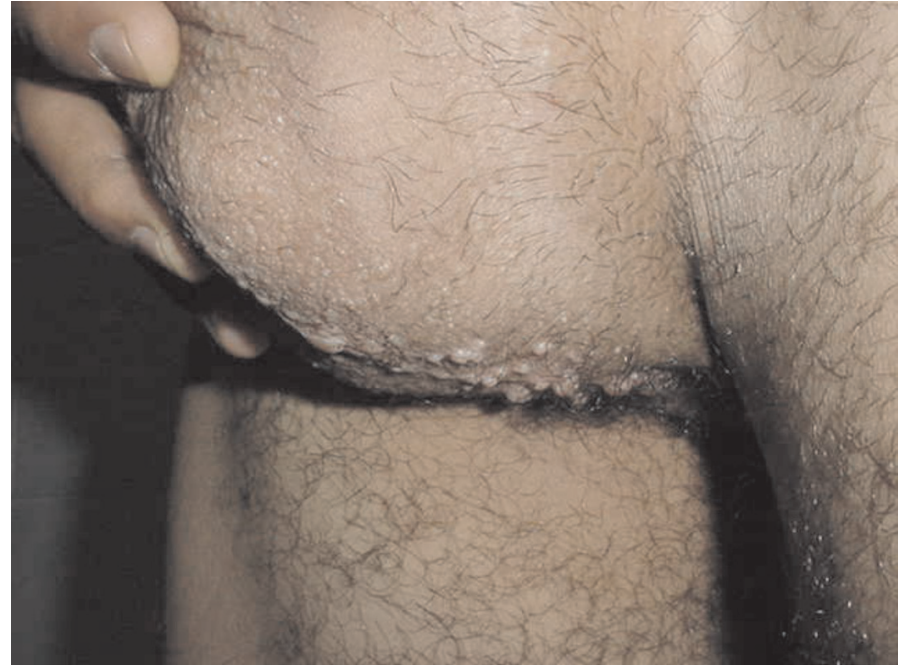

Fig. 1 - Lymph scrotum showing the presence of vesicles forming the site for lymphatic drainage.

\section{MATERIAL AND METHODS}

The National Reference Service for Filariasis (CPqAM/FIOCRUZ) in Recife, Pernambuco State (Brazil) is an outpatient clinic that provides care for individuals who have been identified and referred through research projects coordinated by this clinic. It also provides care for patients referred from various public or private clinics for investigations on filarial disease. A survey was conducted on the medical records of all patients attended between 2000 and 2007 and seven men with a diagnosis of lymph scrotum on admission were identified. These seven cases were admitted between April 2002 and April 2005.

Over the study period, 6,361 patients were attended, of whom 4,280 (67.2\%) were male. All the patients were from the metropolitan region of Recife, which is an endemic area for this disease. The Research Ethics Committee of CPqAM (CEP/CPqAM/FIOCRUZ) gave its approval for this study (CAAE: 0061.0.095.000-07).

All the patients included in this study underwent clinical and urological assessments and laboratory evaluations. The parasitological diagnosis was performed using the technique of filtration on a polycarbonate membrane to investigate microfilariae in nocturnal blood samples (thereby respecting the local periodicity of the microfilariae) ${ }^{10}$. The serological diagnosis was performed using the antigen investigation techniques of ELISA (Enzyme-Linked Immunosorbent Assay) $\mathrm{Og} 4 \mathrm{C} 3^{22}$ and ICT-AD12 (Immunochromatographic Test) ${ }^{29}$.

In addition, scrotal ultrasonography was performed by radiologists with extensive experience in identifying the "filarial dance sign", which consists of movements suggestive of the presence of adult filarial worms of $W$. bancrofti in the lymphatic vessels ${ }^{5}$, as well as to identify other possible urological abnormalities.

The patients received guidance regarding genital hygiene, which is a measure of major importance for managing filarial morbidity. In case of successive acute crises, antibiotic prophylaxis with benzathine penicillin was also used to better control the condition. The patients with positive parasitological tests (microfilaremia) and/or the "filarial dance sign" on ultrasound examination were treated with diethylcarbamazine (DEC), according the WHO recommendations ( $6 \mathrm{mg} / \mathrm{kg} / \mathrm{day}$ for 12 days).

\section{RESULTS}

Seven patients of ages ranging from 26 to 64 years were identified as presenting lymph scrotum. All of them came from urban areas in the metropolitan region of Recife that were recognized to be endemic for Bancroftian filariasis: the cities of Recife, Olinda and Jaboatão dos Guararapes.

The time that had elapsed between the initial clinical manifestations (scrotal pain, increased scrotal volume and localized signs of inflammation) and the diagnosis ranged from two to 15 years. Among the seven patients, five presented previous histories of filarial infection (positive result from the thick smear test at a time prior to the diagnosis of the present study) and only two of these had undergone previous treatment with DEC. All of the patients reported recurrent episodes of acute dermal lymphangioadenitis.

Through complementary investigations, at least one characteristic relating to the etiology of filariasis could be shown in all the patients. Five patients presented microfilaremia. Of these five, only one presented microfilaremia alone; three presented microfilaremia and tested positive for antigens (Og4C3 and ICT), while one had microfilaremia, antigenemia positive for $\mathrm{Og} 4 \mathrm{C} 3$ and adult Wuchereria bancrofti worms ("filarial dance sign" on scrotal ultrasonography). One patient with adult filarial worms who was negative for microfilariae was also serologically positive using the ICT and ELISA Og4C3 techniques. One patient was only positive for $\mathrm{Og} 4 \mathrm{C} 3$ (Table 1).

Among the associated findings detected by means of scrotal ultrasonography and/or urological examination, the following are described in Table 2: lymphangiectasia $(n=5)$, hydrocele $(n=3)$, varicocele $(n=2)$, nodules in the scrotal region $(n=3)$, testicular abnormalities $(n=2)$, epididymal abnormalities $(n=2)$, adenopathy $(\mathrm{n}=1)$ corresponding to bilateral inguinal adenomegaly and scrotal lymphangitis $(n=1)$. The following epididymal and testicular abnormalities were found: textural abnormalities seen on ultrasound, presence of calcifications, increased or decreased testicular volume and presence of a cyst in the head of the epididymis.

Six of the seven patients had undergone some type of urological treatment prior to the appearance of lymph scrotum, but none of them had been followed up from a urological point of view prior to their admission to the National Reference Service, to detect late complications. All of these six patients had undergone hydrocelectomy. Among these six, two had undergone another surgical procedure in addition to hydrocelectomy, one had undergone hernioplasty and one had had surgery to remove a nodule from inside the scrotum. Among the three patients who presented nodules in the scrotum on urological examination, two had already undergone treatment with DEC.

With regard to the orientation of the surgical incision among the six patients with previous hydrocelectomy, three underwent transversal incisions and two had longitudinal incisions (one unilaterally and the other bilaterally), while in one case the orientation was unknown. 
AGUIAR-SANTOS, A.M.; LEAL-CRUZ, M.; NETTO, M.J.; CARRERA, A.; LIMA, G. \& ROCHA, A. - Lymph scrotum: an unusual urological presentation of lymphatic filariasis. A case series study. Rev. Inst. Med. trop. S. Paulo, 51(4): 179-183, 2009.

Table 1

Laboratory results from investigations on the etiology of filariasis in seven patients with lymph scrotum. CPqAM, 2000-2007

\begin{tabular}{|c|c|c|c|c|c|}
\hline \multirow{2}{*}{ Patient } & \multirow{2}{*}{ Age } & \multirow{2}{*}{$\begin{array}{c}\text { Parasitological investigation } \\
\text { Filtration through } \\
\text { polycarbonate membrane }\end{array}$} & \multicolumn{2}{|c|}{ Antigen investigation } & \multirow{2}{*}{$\begin{array}{c}\begin{array}{c}\text { "Filarial dance sign" } \\
\text { investigation }\end{array} \\
\text { Ultrasound }\end{array}$} \\
\hline & & & ELISA Og4C3 & ICT-AD12 & \\
\hline 1 & 28 & + & + & + & - \\
\hline 2 & 41 & + & - & - & - \\
\hline 3 & 26 & - & + & - & - \\
\hline 4 & 64 & + & + & + & - \\
\hline 5 & 33 & + & + & - & + \\
\hline 6 & 36 & + & + & + & - \\
\hline 7 & 55 & - & + & + & + \\
\hline
\end{tabular}

Table 2

Clinical and/or ultrasound findings from patients with lymph scrotum. CPqAM, 2000-2007

\begin{tabular}{|c|c|c|c|c|c|c|c|}
\hline \multirow{2}{*}{ Ultrasound findings / urological evaluation } & \multicolumn{7}{|c|}{ Patients } \\
\hline & 1 & 2 & 3 & 4 & 5 & 6 & 7 \\
\hline Lymphangiectasia & + & - & + & + & - & + & + \\
\hline Hydrocele & + & - & + & - & - & - & + \\
\hline Varicocele & - & - & + & - & - & - & + \\
\hline Nodule inside scrotum & - & - & + & + & - & + & - \\
\hline Adenopathy & - & - & - & - & - & + & - \\
\hline Lymphangitis & - & - & - & - & - & - & + \\
\hline Testicular abnormality & + & - & + & - & - & - & - \\
\hline Epididymal abnormality & - & - & + & - & - & - & + \\
\hline
\end{tabular}

\section{DISCUSSION}

Lymph scrotum almost always occurs in patients with a previous history of acute episodes of filariasis that are characterized by lymphangitis due to bacterial and/or fungal infection, and who present chronic lymphangiectasia ${ }^{13,27}$. This condition may be identified following surgery for chylocele or hydrocele and it is a dermatological manifestation of pathological lymphatic drainage ${ }^{11}$. Its prevalence in endemic areas is unknown: only isolated cases have been reported in the literature ${ }^{1,3,7}$.

The occurrence of acute episodes of dermal lymphangioadenitis due to secondary bacterial infection in lymphatic vessels that are more superficial is the greatest risk factor for the appearance of lymph scrotum ${ }^{11}$. The presence of lymphangiectasia, which is the preponderant factor in the appearance of other clinical presentations of filariasis, was not observed in all of the seven individuals enrolled in this study. Nevertheless, before deeming that the presence of lymphangiectasia is not a factor required for lymph scrotum to appear, the technical difficulty in investigating this anatomopathological substrate needs to be taken into account.

The pathogenesis of lymph scrotum is still not fully defined ${ }^{15,17}$. ACTON \& $\mathrm{RAO}^{1}$ suggested that the appearance of this condition was associated with previous surgery for hydrocele. The surgical technique appears to be an important factor. Although surgeons have recommended partial excision of the sac by means of "bottle neck" inversion of the tunica vaginalis, current thinking is that complete excision with meticulous attention to cauterization of the edges and oversuturing offers the best cosmetic and functional result, with less risk of lymph scrotum $^{11,32}$. Furthermore, the orientation of the scrotal incision seems to have some importance in the appearance of lymph scrotum. Some urologists have chosen to make a transversal incision in the scrotum for esthetic reasons. However, particularly in cases of hydrocele secondary to urogenital filariasis, other surgeons have made the incision longitudinally to avoid sectioning the superficial lymphatic vessels in the skin and subcutaneous tissue, thereby preventing predisposition towards lymph scrotum $^{11}$.

Despite the small number of cases evaluated, the data from the present study suggest that the transversal orientation for the surgical incision may contribute as a predisposing factor towards establishing lymph scrotum. Nonetheless, the transversal orientation should not be defined as the only causal or predisposing factor for lymph scrotum, since two patients who underwent longitudinal incisions, and even one patient without any history of surgery, developed lymph scrotum over the course of their filarial disease. In view of the possibility of late complications such as lymph scrotum or genital lymphedema, patients with hydrocele from endemic areas for LF who have undergone surgery should have clinical follow-up. It needs to be borne in mind that there is no "simple hydrocele" 


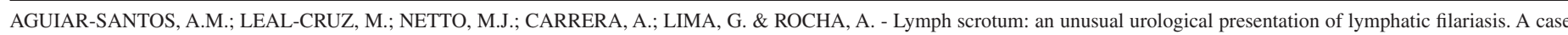
series study. Rev. Inst. Med. trop. S. Paulo, 51(4): 179-183, 2009.

in patients living in endemic areas. Prophylaxis and adequate treatment for episodes of acute dermal lymphangioadenitis in damaged lymphatic systems are essential for reducing the risk factors for lymph scrotum.

The repercussions of lymph scrotum for our patients were dramatic. The constant crises caused by repeated infections with continual drainage of milky secretion prevent them from carrying out their work or leisure activities, and may even have harmed their social interactions. In order to carry out their routine activities, some patients used inventive precautions such as covering the scrotal region with plastic, toilet paper or cloth. At the times of their crises, these patients also complained that it was impossible to have sexual intercourse. Moreover, the repeated infections could evolve into a condition of scrotal elephantiasis. All these circumstances together caused psychological stress that could lead these patients to depression.

With regard to the clinical evolution of the disease, it was observed that this took place over a long period ranging from two to 15 years. Thus, this presentation was characterized as chronic, just like lymphedema ${ }^{3}$. Among the five patients with a previous history of filariasis, only two had undergone treatment with DEC. The importance of the treatment in these patients is reflected in two ways. Firstly, at the individual level, lack of treatment for individuals with microfilaremia may have an influence on the time taken for the disease to evolve and thus make it possible for greater morbidity to occur. Secondly, it brings out a particular feature observed in relation to the disease transmission chain. This concerns the finding that five patients presented filarial morbidity and microfilaremia. In clinical practice, it has commonly been observed that patients with chronic disease do not present microfilaremia ${ }^{5,12,28}$. However, even knowing that the group of patients with chronic manifestations of filariasis is not the principal source involved in the transmission chain, this possibility cannot be ignored. Thus, treatment for these individuals when they present microfilaremia may be of fundamental importance for controlling transmission. Furthermore, it is important to highlight the fact that these individuals continue to live in endemic areas, with the risk of reinfection. Therefore, they must be included within the local filariasis control program, either in mass drug treatment or in routine individual investigation. Since DEC must not be given because of potential side effects during coinfection with onchocerciasis, the recommended treatment in these regions is a single dose of ivermectin and albendazole ${ }^{18}$.

It has been recognized in endemic areas that the formation of intrascrotal nodules following treatment with antifilarial drugs (or spontaneously) expresses the death of adult worms. Thus, the finding of these nodules, together with other information, may be taken to be an indirect sign of previous filarial infection. This may be useful in relation to monitoring the macrofilaricidal effect of drugs ${ }^{5,16,23}$. In this case series, the presence of nodules was detected in three patients, of whom two had made use of DEC.

Chronic filarial manifestations cannot be cured, but their spread and future cases can be prevented through delivery of drug combinations to populations where the disease is prevalent. The treatment for this morbid condition is based on conservative measures that avoid its progression. These measures consist of local hygiene care, in the same way as proposed for lymphedema in the limbs, and antibiotic prophylaxis using benzathine penicillin ${ }^{3}$. However, in some cases, surgical reconstruction has been shown to be efficient ${ }^{11}$, considering that this chronic disease is of irreversible nature.
Urogenital surgery is considered by WHO to be a critical point in controlling filarial morbidity, with the aim of minimizing the incapacitation produced by the effects of this disease in man ${ }^{11}$. Among the urogenital surgical approaches, surgery for hydrocele has been the key point within control programs for this morbid condition, and surgical guidelines are available from WHO for endemic filariasis areas ${ }^{32}$. However, lymph scrotum and other urogenital manifestations such as scrotal elephantiasis and chyluria have received less attention from the global program for eradication of lymphatic filariasis ${ }^{2}$.

Knowledge of the profile of lymph scrotum patients highlights the importance of adequate surgical approaches towards hydrocele cases in endemic areas, with the aim of eliminating a possible risk factor for the appearance of this condition. It also highlights the importance of appropriate surgical and clinical management of this morbid condition. The need for laboratory investigation and specific treatment is emphasized in this management, with the aim of impeding progression within the clinical evolution of the disease and breaking the transmission chain, since even patients with the morbid condition may present microfilaremia. Furthermore, the importance of knowing these patients' profile is emphasized with regard to discussing the viability of reparative surgical approaches for the condition of lymph scrotum.

There is no consensus on the management methods for different urogenital manifestations. There is an urgent need to develop such a consensus, by means of reviews and expert group discussions ${ }^{25}$. The points made here have had the aim of contributing towards improving the filariasis control actions, in accordance with the guidelines of the global program for elimination of lymphatic filariasis.

\section{RESUMO}

\section{Linfoescroto: apresentação rara de filaríase linfática. Estudo retrospectivo}

A filariose linfática (FL) é responsável por uma grande variedade de sinais e sintomas clínicos incluindo manifestações urogenitais. O controle da transmissão e da incapacitação bem como o manuseio da morbidade são os dois pilares da estratégia global de eliminação da FL. O linfoescroto é uma rara apresentação da FL, tendo importantes repercussões do ponto de vista clínico, psicológico e socioeconômico. Realizou-se um estudo retrospectivo de uma série de casos com diagnóstico de linfoescroto, identificados entre os 6.361 pacientes ambulatoriais atendidos no período de 2000 a 2007 no Serviço de Referência Nacional em Filarioses (Recife, Brasil) área endêmica de filariose. Foram identificados sete casos, com a idade média de 45 anos (com variação de 26 a 64 anos). O tempo médio de evolução da doença foi de 8,5 anos (com variação de 2 a 15 anos). Todos apresentavam evidência de infecção filarial por algum dos exames realizados (parasitológico, pesquisa antigênica ou "sinal da dança da filaria" na ultrasonografia). Seis pacientes relatavam historia prévia de cirurgia urológica. Os autores destacam a importância da associação da infecção filarial e de inadequado manuseio cirúrgico e de acompanhamento de pacientes com hidrocele de uma área endêmica, como fatores de risco para o surgimento de linfoescroto. Assim, a infecção filarial deve ser rotineiramente investigada em todos os indivíduos procedentes de áreas endêmicas apresentando morbidade urológica, para identificar melhor os elementos da cadeia de transmissão. 


\section{ACKNOWLEDGEMENTS}

This work was supported by Centro de Pesquisas Aggeu Magalhães/ Departamento de Parasitologia/SRNF (project \# 573-17, 814/2006 FIOTEC/SVS) and FACEPE (process no. 25380.004212/2004-00, accord no. 55/2004-CPqAM/FIOCRUZ).

\section{REFERENCES}

1. ACTON, H.W. \& RAO, S.S. - The causation of lymph scrotum. Indian med. Gaz. 65: $541-546,1930$

2. ADDISS, D.G. - Global elimination of lymphatic filariasis: origins, progress and challenges. Indian J. Urol., 21: 12-17, 2005.

3. ADDISS, D.G. \& BRADY, M.A. - Morbidity management in the Global Programme to Eliminate Lymphatic Filariasis: a review of the scientific literature. Filaria J., 6 : $2,2007$.

4. AGUIAR-SANTOS, A.M.; NETTO, M.J.; MEDEIROS, Z. \& de ANDRADE, L.D - Filaríases. In: VERONESI, R. \& FOCACCIA, R.. ed. Tratado de Infectologia. São Paulo, Atheneu, 2005. p. 1735-1756.

5. ALBUQUERQUE, M.F.P.M. - Urbanização, favelas e endemias: a produção da filariose no Recife, Brasil. Cadern. Saúde públ. (Rio de J.), 9: 487-497, 1993.

6. AMARAL, F.; DREYER, G.; FIGUEREDO-SILVA, J. et al - Live adult worms detected by ultrasonography in human Bancroftian filariasis. Amer. J. trop. Med. Hyg., 50: 753-757, 1994

7. BELOKAR, W.K.; DE SA, O.O.; AMONKAR, D.P.; DHARWADKAR, A.M. \& PRIOLKAR, R.P. - Uncommon manifestations of filariasis. J. Postgrad. Med., 29: 170-174, 1983.

8. BONFIM, C.; LESSA, F.; OLIVEIRA, C. et al. - Situação da filariose bancroftiana na região metropolitana do Recife: estudo em uma area endêmica no município de Jaboatão dos Guararapes, Pernambuco, Brazil. Cadern. Saúde públ. (Rio de J.), 19: $1497-1505,2003$

9. DAS, P.K.; PANI, S.P. \& KRISHNAMOORTHY, K. - Prospects of elimination of lymphatic filariasis in India. ICMR Bull. 32 (5 \& 6): 41-54, 2002.

10. DENNIS, D.T. \& KEAN, B.H. - Isolation of microfilariae: report of a new method. J. Parasit., 57: 1146-1147, 1971.

11. DE VRIES, C.R. - The role of the urologist in the treatment and elimination of lymphatic filariasis worldwide. BJU Int., 89(suppl. 1): 37-43, 2002.

12. DISSANAYAKE, S. - In Wuchereria bancrofti filariasis, asymptomatic microfilaraemia does not progress to amicrofilaraemic lymphatic disease. Int. J. Epidem., 30: 394 399,2001

13. DREYER, G.; FIGUEIREDO-SILVA, J.; NEAFIER, C. \& ADDISS, D.G. - Lymphatic filariasis. In: NELSON, A.M. \& HORSBURG, R.C., ed. Pathology of emerging infections 2. Washington, American Society of Microbiology, 1998. p. 317-342.

14. DREYER, G. \& DREYER, P. - Bases para o tratamento da morbidade em áreas endêmicas de filariose bancroftiana. Rev. Soc. bras. Med. trop., 33: 217-221, 2000.

15. DREYER, G.; NORÕES, J.; FIGUEREDO-SILVA, J. \& PIESSENS, W.F. Pathogenesis of lymphatic disease in Bancroftian filariasis: a clinical perspective. Parasit. today, 16: 544-548, 2000.

16. DREYER, G.; ADDISS, D.; WILLIAMSON, J. \& NORÕES, J. - Efficacy of coadministered diethylcarbamazine and albendazole against adult Wuchereria bancrofti. Trans. roy. Soc. trop. Med. Hyg., 100: 1118-1125, 2006.
17. GYAPONG, M.; GYAPONG, J.; WEISS, M. \& TANNER, M. - The burden of hydrocele in North Ghana. Acta trop., 77: 287-294, 2000.

18. HOERAUF, A. - Filariasis: new drugs and new opportunities for lymphatic filariasis and onchocerciasis. Curr. Opin. infect. Dis., 21: 673-681, 2008.

19. MEDEIROS, Z.M.; OLIVEIRA, C.M.; QUARESMA, J. et al. - A filariose bancroftiana no município de Moreno - PE, Brasil. Rev. bras. Epidem., 1: 73-79, 2004

20. MEDEIROS, Z.M.; ALVES, A.; BRITO, J.A. et al. - The present situation regarding lymphatic filariasis in Cabo de Santo Agostinho, Pernambuco, northeast Brazil. Rev. Inst. Med. trop. S. Paulo, 48: 263-267, 2006.

21. MINISTÉRIO DA SAÚDE. Superintendência de Campanhas de Saúde Pública - O controle de endemias no Brasil (de 1979 a 1984). Brasília, 1985. 154p.

22. MORE, S.J. \& COPEMAN, D.B. - A highly specific and sensitive monoclonal antiboby based ELISA for the detection of circulating antigen in bancroftian filariasis. Trop. Med. Parasit., 41: 403-406, 1990.

23. NOROES, J.; ADDISS, D.; CEDENHO, A. et al. - Pathogenesis of filarial hydrocele: risk associated with intrascrotal nodules caused by death of adult Wuchereria bancrofti. Trans. roy. Soc. trop. Med. Hyg., 97: 561-566, 2003.

24. OTTESEN, E.A. - The global programme to eliminate lymphatic filariasis. Trop. Med. Int. Hlth, 5: 591-594, 2000.

25. PANI, P.; KUMARASWAMI, V. \& DAS, L.K. - Epidemiology of lymphatic filariasis with special reference to urogenital manifestations. Indian J. Urol., 21: 44-49, 2005.

26. SEIM, A.R.; DREYER, G. \& ADDISS, D.G. - Controlling morbidity and interrupting transmission: twin pillars of lymphatic filariasis elimination. Rev. Soc. bras. Med. trop., 32: 325-328, 1999.

27. SHENOY, R.K.; SANDHYA, K.; SUMA, T.K. \& KUMARAWSWAMI, V. - A preliminary study of filariasis related acute adenolimphangitis with special reference to precipitating factors and treatment modalities. Southeast Asian J. trop. Med. publ. Hlth, 26: 301-305, 1995.

28. SIMONSEN, P.E.; MEYROWITSCH, D.W.; MAKUNDE, W.H. \& MAGNUSSEN, P. - Bancroftian filariasis: the pattern of microfilaraemia and clinical manifestations in three endemic communities of Northeastern Tanzania. Acta trop., 60: 179-187, 1995.

29. WEIL, G.J.; LAMMIE, P.J. \& WEISS, N. - The ICT filariasis test: a rapid-format antigen test for diagnosis of bancroftian filariasis. Parasit. today, 13: 401-404, 1997

30. WORLD HEALTH ORGANIZATION - The World Health Report: bridging the gaps. Geneva, WHO, 1995.

31. WORLD HEALTH ORGANIZATION - Preparação e Implementação de um Plano Nacional para Eliminar a Filaríase Linfática: guia para gerentes de programas. Eliminação da Filaríase Linfática (CPE/CEF/FIL) Controle, Prevenção e Erradicação. 2000.

32. WORLD HEALTH ORGANIZATION - Surgical approaches to the urogenital manifestations of lymphatic filariasis. Geneva, World Health Organization, 2002. p. $1-29$.

33. WORLD HEALTH ORGANIZATION - Global Programme to Eliminate Lymphatic Filariasis. Wkly Epidem. Rec., 122: 221-232, 2006.

34. WORLD HEALTH ORGANIZATION - Global Programme to Eliminate Lymphatic Filariasis. Wkly Epidem. Rec., 42 (82): 361-380, 2007.

Received: 5 December 2008

Accepted: 4 June 2009 